\title{
The Gender Politics of Confucian Family Law: Contracts, Credit, and Creole Chinese Bilateral Kinship in Dutch Colonial Java (1850s-1900)
}

\author{
GUO-QUAN SENG \\ National University of Singapore, History Department
}

The Indies-Chinese woman is ... much less capable of exercising rights than her sister in China. She is usually a scantly developed, very sensual being, who becomes the tool of her male relatives after the death of her husband. ${ }^{1}$

P. Meeter, Government Translator for Chinese, Surabaya, May 1879

For much of the second half of the nineteenth century, Dutch colonial courts and their Sinology-trained advisers in Java struggled to come to terms with the legal uncertainty created by the autonomy of Peranakan Chinese women inheriting, transacting, bequeathing lands and wealth, and sometimes simply trading as merchants. Advising the colonial authorities on handling Chinese probate and bankruptcy cases, P. Meeter's comments in the Indies law journal, just quoted, summed up how the Dutch legal ethnographic state framed the problem as one of inadequate morals and affinal interference in patrilineal succession: compared to Chinese women in China, the local born Peranakan Chinese woman of mixed origins and culture was being exploited by her agnatic kin at the expense of her husband's patrilineal heirs.

Ong Kwie Nio would have appeared to be such a woman to the colonial authorities. $^{2}$ On 8 November 1878 , Kwie Nio made a loan of f290,000 Indies

Acknowledgments: Research for this paper was funded by a Social Science Research Council, International Dissertational Research Fellowship (2012-2013). I would like to thank Mark Philip Bradley, Tamara Loos, Prasenjit Duara, and the CSSH reviewers for their comments on earlier drafts.

1 P. Meeter, "De Regtstoestand der Chineesche Vrouw," in Het Regt van Nederlandsch-Indië (henceforth, HRNI) 32 (1879): 345-73, 371.

2 Arsip Nasional Republik Indonesia (National Archives Republic of Indonesia, henceforth, ANRI), Arsip Wees- en Boedelkamer 1819-1937 (Archives of the orphans and probate court), file 1746, Ong Boen Seng; "Ong Kwi Nio ca. De Weeskamer te Batavia, Raad van Justitie te 
(gulden) to her brother Ong Boen Seng before the clerk in the Raad van Justitie (court of justice) for Europeans in Batavia. When Boen Seng died intestate (i.e., leaving no testament) three years later, his brother-in-law, Kapitan Oeij Tjiang Piauw of the neighboring district of Tangerang, applied to the colonial probate court to be the legal guardian for Ong Boen Seng's minor children. Kwie Nio and her husband became embroiled in an eight-year-long moral-legal feud with the probate authorities over the guardianship and control of Boen Seng's family and estate during the 1880s. It was in the process of this feud, I will argue, that contradictions between creolized Chinese kinship, gendered "Chinese" Confucian family law, and the doctrine of contracts surfaced in the historical record. ${ }^{3}$

These contradictions were at the center of the gender politics of constructing Confucian family law for the Peranakan Chinese of Java. In 1855, the Dutch colonial state incorporated Chinese subjects in Java into the European, upper-half of the dualist legal system (Dutch civil and commercial law, and the European courts Raden van Justitie) for commercial disputes, while native Javanese and other Indonesians remained under the jurisdiction of adat-law native courts (Landraden). ${ }^{4}$ This set the stage for a clash between the Southeast Asian bilateral mode of tracing descent, transmitting wealth, and pooling credit practiced by the creole Chinese families, and the increasingly patrilineal Confucianist interpretations of "Chinese" family law in the colonial courts during the latter half of the century.

While the literature on colonial Indonesia has tended to view the Dutch colonial preservation of adat (customary) law as helping to preserve Indonesian women's autonomy and property rights, this essay shows how in the case of the Indonesian-Chinese entrepreneurial minority, the colonial government's institutionalization of Confucian "Chinese" family law gradually introduced more patriarchal norms for creole Chinese families. John Bowen's legal ethnography of the Gayo highlands, for instance, takes for granted that bilateral inheritance under adat legal norms from the 1920s and 1930s had always been part of an Indonesian "village repertoire" for resolving disputes. ${ }^{5}$ Anthony Reid's image of the relative autonomy of women in early modern Southeast Asia is at least partially projected backward from Dutch colonial adat law surveys

Batavia, 2 April 1886," in Indische Weekblad van het Recht (henceforth, IWR), no. 1236, 1887, $41-44$.

3 I use the Anglo-American "family law" in this essay for what is referred to as "private law" (privaatrecht) in Dutch and continental legal usage. I retain "private law" to refer to specific private law codes.

${ }^{4}$ Daniel Lev, "Colonial Law and the Genesis of the Indonesian State," Indonesia 40 (1985): $57-74$.

5 John Bowen, Islam, Law and Equality in Indonesia: An Anthropology of Public Reasoning (Cambridge: Cambridge University Press, 2003), 22-63. 
(adatrechtbundels) from the early twentieth century. ${ }^{6}$ Likewise, the patrilineal and patriarchal structure of the creolized Chinese family is still often taken as a given if not defining characteristic of the culture-bound overseas Chinese. ${ }^{7}$

This essay contends instead that the Dutch colonial state's legal regulation of credit and commerce in Java took a moralistic turn in the mid-nineteenth century, giving shape to a more patriarchal and "Chinese" form of the family in Java by the century's end. This legal-moralistic turn took the form of a critique of creole Chinese women on one hand, and the Sinological construction of a body of Confucian "Chinese" family law on the other. But for almost half-a-century, this encroaching colonial ethno-moral critique of creole Chinese credit and family matters came up against resistance from Peranakan Chinese matriarchs and patriarchs. To delineate the gender politics of colonialmade Confucian family law, this essay analyzes how the bilateral structure of creole Chinese business families came to clash with the colonial state's new ethno-moralistic approach to law.

Until recently, the scholarship on Southeast Asian colonial law has focused on its unique system of pluralist accommodation of ethno-cultural differences without considering how the processes of colonial law shaped sociocultural structures and communal differences over the longer duration. ${ }^{8}$ New works have begun to reveal the extent of socio-cultural change wrought by colonial intervention in family law in the nineteenth century. Nurfadzilah

${ }^{6}$ Anthony Reid, Southeast Asia in the Age of Commerce, Volume 1: The Lands below the Wind (New Haven: Yale University Press, 1988), 120-72. Reid's most recent take on this issue indicates that he sees continuity in women's relative autonomy through the colonial and early postcolonial periods, up to the eve of industrialization in the region in the 1970s; "Patriarchy and Puritanism in Southeast Asian Modernity," DORISEA Working Paper Series 8 (2014): 7. For two countrybased critiques, see Nhung Tuyet Tran, "Gender, Property, and the 'Autonomy Thesis' in Southeast Asia: The Endowment of Local Succession in Early Modern Vietnam," Journal of Asian Studies 67, 1 (2008): 43-72; Chie Ikeya, "The 'Traditional' High Status of Women in Burma: A Historical Reconsideration,” Journal of Burma Studies 10 (2005/2006): 51-81.

7 Chen Menghong, De Chinese Gemeenschap van Batavia, 1843-1865: Een onderzoek naar het Kong Koan-archief (The Chinese community of Batavia, 1843-1865: a study from the Kong Koan Archive) (Leiden: Leiden University Press, 2011), ch. 5; and Patricia Tjiook-Liem, De Rechtspositie der Chinezen in Nederlands-Indië 1848-1942 (The legal position of the Chinese in Netherlands-India) (Leiden: Leiden University Press, 2009), 157-61.

8 M. B. Hooker, Legal Pluralism: An Introduction to Colonial and Neo-Colonial Laws (Oxford: Clarendon Press, 1975); Cees Fasseur, "Cornerstone and Stumbling Block: Racial Classification and the Late Colonial State in Indonesia," in E. Nathaniel Gates, ed., Racial Classification and History (New York: Routledge, 1997), 37-56; Robert Cribb, "Legal Pluralism and Criminal Law in the Dutch Colonial Order," Indonesia 90 (2010): 47-66; Wim Wertheim, "Political Status of the Chinese in Pre-War Netherlands Indies," Indonesian Law and Adminsitration Review 3, 2 (1997): 6-27; Patricia Tjiook-Liem, “The Loa Joe Djin-Case: A Trigger to Change," in Marleen Dieleman, Juliette Koning, and Peter Post, eds., Chinese Indonesians and Regime Change (Leiden: Brill, 2010), 117-38. See also, M. B. Hooker, "English Law and the Invention of Chinese Personal Law in Singapore and Malaysia," in M. B. Hooker, ed., Law and the Chinese in Southeast Asia (Singapore: ISEAS, 2002), 95-130; M. B. Hooker, “The 'Chinese Confucian' and the 'Chinese Buddhist' in British Burma, 1881-1947,', Journal of Southeast Asian Studies 21, 2 (1990): 384-401. 
Yahaya has shown how the passing of the "Mohamedan Marriage Ordinance" in 1880 coalesced an "Islamic" communal identity around colonial Singapore's wealthy Arab patriarchal elites, at the expense of Malay or other regional adat laws and ethnic identities. ${ }^{9}$ Tamara Loos argues that virile conceptions of Siamese royal-nationalist selfhood both delayed the passing of a modern monogamous family law, and spurred the adoption of Islamic personal law courts in Siam's southern provinces. ${ }^{10}$ These new works notwithstanding, Southeast Asianists have yet to debate the role of colonial law in changing social structural norms at a conceptual level.

In the South Asian field, while there is a general consensus that colonial law reified native patriarchies, the structure of South Asian women's autonomy and agency under ethno-religious colonial legal rule remains a contested question. ${ }^{11}$ Legal historians tend to see colonial law as a processual "discursive framework that guides and sets the social templates through which Indian subjects were forced to interact with the state."12 For Muslim divorces in British India, Mitra Sharafi asserts that "semi-autonomous" and "chivalric imperialist" British judges encouraged indirect means (inflated dower) to subvert the divorce rights of Muslim men. ${ }^{13}$ Colonial law gave female subjects new if incremental autonomies.

Other scholars, who see a more fundamental rupture after colonization, tend to highlight the socio-political effects of colonial administered religious family law. For these scholars, the question is less about measuring women's legal rights post-colonization than analyzing the colonial politics of resolving intra-Indian disputes in the field of law. Mytheli Sreenivas contends that colonial family law neutralized the preexisting politics of "affect and alliance within and among" Tamil zamindari households, and replaced the high-stakes royal sexual political-economy with a discourse of "Dharmic conjugality." "For matrilineal Malabar, G. Arunima shows how colonial administered religious

\footnotetext{
9 Nurfadzilah Yahaya, "Craving Bureaucracy: Marriage, Islamic Law, and Arab Petitioners in the Straits Settlements," Muslim World 105, 4 (2015): 496-515.

${ }^{10}$ Tamara Loos, Subject Siam: Family, Law, and Colonial Modernity in Thailand (Ithaca: Cornell University Press, 2006).

11 Mitra Sharafi writes against "the view of many scholars that colonial judges reinforced patriarchal power structures in direct and immediate ways." See her, "The Semi-Autonomous Judge in Colonial India: Chivalric Imperialism Meets Anglo-Islamic Dower and Divorce Law," Indian Economic \& Social History Review 46, 1 (2009): 57-81, 60. While Sharafi makes a persuasive counterargument through her review of case law judgements on Muslim divorces in British India (see below), I am less inclined, as are most of the other studies discussed by her, to treat colonial judges as "semi-autonomous" agents in the colonial legal system.

12 Eleanor Newbigin, Leigh Denault, and Rohit De, "Introduction: Personal Law, Identity Politics and Civil Society in Colonial South Asia," Indian Economic \& Social History Review 46, 1 (2009): 1-4, 1.

13 Sharafi, "Semi-Autonomous Judge."

14 Mytheli Sreenivas, Wives, Widows and Concubines: The Conjugal Family Ideal in Colonial India (Bloomington: Indiana University Press, 2008), 18-44.
} 
law had the "tendency ... to subordinate questions of [matrilineal Nayar] 'custom' to [text-based Brahmanical] law," favoring men as heirs, landowners, and professionals in the nineteenth century. ${ }^{15}$ Over the long duration, colonial law depoliticized intra-Indian disputes by consigning them to the religious or family law domain, and standardized their resolution by affixing sacred textbased rationales as ethno-religious justice.

The creole Chinese of Java went through a similar gradualist social-legal transformation in the latter half of the century. Dutch colonial family law had the tendency to depoliticize creole Chinese family-business alliances and entrench Confucian texts as the authoritative "Chinese" legal textual over preexisting oral-communal sources of law. I assert that this law-based, depoliticizing tendency came up against what were essentially the affinal and matrilateral credit and wealth manipulation networks of the creole Chinese families. ${ }^{16}$ To understand the long-term gender effects of colonial family law-making, I recover the affinal and matrilateral in creole Chinese business alliances in order to highlight the social-cultural basis of their conflict with colonial Confucian "Chinese" family law.

I begin by outlining the configuration of social factors that gave rise to the bilateral kinship patterns of the creole Chinese in Java. A case study of the Ongs and Oeijs of Tangerang emphasizes the salience of affinal and matrilateral connections in marriage alliances and trade in the colony. Two sections follow that explore Dutch attempts to regulate Chinese marital property in Java by (1) legislating separate estates, and (2) constructing a legal discourse of Confucianist ethical family law. This will set the stage in the fourth section for Ong Kwie Nio's clash with the probate authorities in the Supreme Court over the legality of an allegedly fictitious loan, which I maintain pitted the bilateral moral obligations and interests of the creole Chinese kinship families against the newly constructed colonial theories about Chinese patrilineal law. Although Ong won her case by deft contractual and kinship maneuvers, I show in the last section how such maneuvers also persuaded Dutch jurists, otherwise sympathetic to Chinese women's property rights, to settle for Confucianist ethical law as the official "national" law for the creole Chinese in Java.

15 G. Arunima, 'There Comes Papa': Colonialism and the Transformation of Matriliny in Kerala, Malabar c. 1850-1940 (Hyderabad: Orient Longman, 2003), 17. See also Radhika Singha's discussion, "The Magistrate and the Domestic Sphere," in her A Despotism of Law: Crime and Justice in Early Colonial India (Oxford: Oxford University Press, 1998), 121-67.

16 Here, I am borrowing from Susan McKinnon's critique of Evans-Pritchard's separation of patrilineal kinship from the politics of Nuer alliance making, which she says "suppresse[s] the political significance of affinal and matrilateral relations" (her emphasis). See her "Domestic Exceptions: Evans-Pritchard and the Creation of Nuer Patrilineality and Equality," Cultural Anthropology 15, 1 (2000): 35-83, 48. 
WEALTH, WOMEN, AND BILATERAL FAMILIES

By the end of the eighteenth century, the structures for the development of what William Skinner called a creolized Chinese intermediate society wedged between the native and the European colonial groups on Java were in place. ${ }^{17}$ In Java, due to Dutch restrictions on Chinese immigration, their numbers in relation to the indigenous Javanese population remained consistent throughout the nineteenth century. ${ }^{18}$ Like their Baba Chinese and Chinese Mestizo counterparts in the British Straits Settlements and the Spanish Philippines, the Peranakans in Java were the descendants of male Chinese settlers who intermarried with indigenous women, and tended to prefer endogamy in subsequent generations. Upward social mobility along with exclusion from European circles gave these societies a distinctly stable creolized Chinese culture. ${ }^{19}$ Skinner concluded from his mostly twentieth-century ethnographic evidence that the Peranakan Chinese kinship system had "shifted away from the patrilineal, virilocal, and patriarchal bias of the traditional Hokkien (Fujian) system," into an "essentially bilateral ... system," where there was a "distinct tendency in the ancestral cult to worship the lineal ascendants of the mother as well as of the father." ${ }^{20}$ The inheritance and dowry that Chinese daughters brought to their uxorilocal or neolocal households became part of the marital property, and it formed shared capital for creole Chinese women's continued stakes in their father's/brother's and her husband's families.

Creole Chinese men were conscious of two different sets of inheritance norms for Chinese women in China and Java (Batavia). While the preference for patrilineal inheritance was retained, creole Chinese men displayed a fair degree of openness for their daughters to inherit besides receiving a dowry at

${ }^{17}$ William Skinner, "Creolized Chinese Societies in Southeast Asia," in Anthony Reid, ed., Sojourners and Settlers: Histories of Southeast Asia and the Chinese (Sydney: Allen and Unwin, 1996), 50-93.

${ }^{18}$ From $62,000: 4.5$ million (1815), to $170,000: 16$ million (1870), to $230,000: 28$ million (1900). See P. Boomgaard and A. J. Gooszen, eds., Changing Economy in Indonesia: A Selection of Statistical Source Material from the Early $19^{\text {th }}$ Century up to 1940, Volume 11, Population Trends 1795-1942 (Amsterdam: Royal Tropical Institute, 1991), 98, 117, 125, 135.

19 This was most notable in the Dutch upholding, with no apparent resistance, Qing-Chinese sumptuary law, religious practices (Buddhist, folk deity, and ancestral worship), and the retention of Hokkien in their creolized Malay language. Chen Menghong has found that the majority of marriages in Batavia between 1843 and 1865 were patrilocal although "uxorilocal marriages are also to be found"; De Chinese, 128-29, 147.

${ }^{20}$ Skinner, "Creolized Chinese Societies," 62-63. More recent research into Batavia Chinese Council marriages largely agrees with Skinner's depiction of the bilateral pattern of Peranakan kinship. Chinese marriage registers in Batavia show that for the periods 1869-1873 and 18911894, one in four marriages involved a China-born groom with a local creole Chinese bride. See Hans Gooszen, "The Marriage Market for Chinese Girls in Batavia: Some Explorations into Its Territorial Boundaries," in Leonard Blusse and Chen Menghong, eds., The Archives of the Kong Koan of Batavia (Leiden: Brill, 2003), 69-80. 
marriage. When queried by the Batavia Dutch colonial resident about Chinese women's rights to inherit and perform ancestral worship in 1861, the Batavia Chinese Council had few differences in opinions. They explained that while women in China were entitled to a dowry at marriage, they did not inherit. Their loyalty was to their husbands after marriage, and thus they had no need to attend to their father's ancestral worship. For Chinese women in Batavia, however, "There are some who inherit. If the deceased has male descendants, then they pay for the ancestral offerings. The daughters may contribute if they so wish. It is fine if they do not, but they definitely have to obey the wishes of their husbands. ${ }^{21}$ In another survey of Chinese inheritance norms four years later, the assembled Kapitans replied that in the absence of a testament, an unmarried daughter would inherit one-sixth the share of the primary wife's son, one-third that of the secondary wife's son, or one-half that of the primary wife. ${ }^{22}$ No doubt the preferred mode of wealth transmission was still patrilineal, but creole Chinese widows and daughters had definite minority shares in their family's estates.

Ong Kwie Nio's story illustrates how women's wealth in uxorilocal or neolocal marriages made it difficult for colonial authorities to distinguish the economic boundaries between bilaterally allied families. ${ }^{23}$ To begin with, women in the Ong family inherited and retained their wealth in their new households. Kwie Nio's father, Ong Siew Ko, was a Batavia Chinese who had owned the lucrative market license and several parcels of land in Tangerang since 1823, and died in 1836. He divided in his will his lands among two sons, while his surviving (secondary) wife and two daughters received significant sums of money and life-long usufruct rights to rental income. ${ }^{24}$ The Ong's went on to forge at least two if not three generations of cross-cousin marital exchanges with the local Oeij's of Tangerang: (1) Siew Ko's marriage with his secondary wife Oeij Gin Nio; (2) the above-mentioned uxorilocally married Kwie Nio, with Kapitan Oeij Tjiang Piauw; and (3) the marriage between Kwie Nio's daughters and her brother, Boen Seng's sons. ${ }^{25}$ While the Tangerang lands were co-owned by Ong Boen Seng and his patrilateral

${ }^{21}$ Leiden University Library, The Kong Koan Archive, 2.1 Minutes, 7 June 1861.

${ }^{22}$ Kong Koan Archive, 2.1 Minutes, 22 February 1865. For Chinese ab-intestato cases, the probate court in Batavia in fact applied European inheritance law; that is, equal inheritance for surviving spouse and all children. A. A. Buyskes, Academisch proefschrift over de Weeskamer en het Collegie van boedelmeesteren te Batavia [Academic thesis on the Orphans Court and the College of Probate Masters in Batavia] (Leiden: Hoek, 1861), 114-15.

${ }^{23}$ For an alliance between the Tans and Oeijs of Batavia, see Chen, Chinese Gemeenschap, 39-40. James R. Rush notes that three "family groups" controlled thirteen of Java's twenty opium farms in 1887-1889. See his Opium to Java: Revenue Farming and Chinese Enterprise in Colonial Indonesia, 1860-1910 (Ithaca: Cornell University Press, 1990), 92-96.

24 "Ong Kwe Nio ca. De Weeskamer te Batavia," ibid.

${ }^{25}$ Kwie Nio's mother was Oeij Gin Nio. For her close relationship with her nephew/son-in-law, see Kapitan Oeij's testimony at a hearing in the Kong Koan Archive, 2.1 Minutes, 1 July 1864. 
nephews, it was Ong Kwie Nio and her husband who lived there and leased the lands in a typical creole Chinese uxorilocal marriage. In a further sign of their entangled interests, Ong Boen Seng appointed his brother-in-law to be his representing agent for the last twenty years of his life.

This creole pattern of Chinese kinship in Java was part of the local fabric of bilateral kinship that flourished especially in early modern commercial societies across Southeast Asia. The highly fluid structure of commerce in the colony and influence from Javanese kinship patterns moved Chinese settler families away from the virilocal pattern of residence, giving married women in general, and widows in particular, a greater role to play in manipulating the wealth and marriages of their respective lineal families. Dutch jurists struggled to bring civil law's notion of the conjugal household in line with the economic workings of the creole Chinese family. To secure the interests of European creditors, the colonial government found itself having to introduce the concept of contractually separate estates between Chinese couples.

\section{REGULATING CHINESE MARITAL PROPERTY}

As intermediaries between European importers/exporters and native producers/ consumers in the agrarian hinterland, Chinese merchants traded on European credit, and bore the risk of price fluctuations and harvest failures between consignments. Like their Marwari "vernacular capitalist" counterparts in colonial Bombay, the Chinese in colonial Java made complex transactions that blurred the line between security and speculation. ${ }^{26}$ From 1856 to 1942 , between half and three-quarters of all bankruptcies involved ethnic Chinese merchants. ${ }^{27}$ Responding to European creditors' concerns about fraudulent transfers of property to the bankruptee's wife, the colonial state moved to regulate Chinese marital property by legislatively demanding contractually provable separate estates.

Until the 1855 colonial legislation, statutory law from the Company era still in force in the colonial period had recognized Chinese women's separate marital estates out of pragmatic concern for their welfare and respect for the creole Chinese women's adherence to the Islamic law-influenced local custom. The 23 May 1766 Company Statute for Batavia maintained the existing status quo regarding the Chinese women's default right to separate estates from their husbands, and the latter's debts. It was pragmatic law for "times like these, when not so many wealthy Chinese are to be found, and so not much can be misappropriated by the surviving widow." The statute also recognized that

${ }^{26}$ Ritu Birla, Stages of Capital: Law, Culture, and Market Governance in Late Colonial India (Durham: Duke University Press, 2009), 143-19; Alexander Claver, Dutch Commerce and Chinese Merchants in Java: Colonial Relationships in Trade and Finance, 1800-1942 (Leiden: Brill, 2014), esp. 351-71.

${ }_{27}$ Alexander Claver and Thomas Lindblad, "Going Bankrupt? Business Failure in Colonial Indonesia, 1870-1940," Economics and Finance in Indonesia 57, 2 (2009): 139-57, 140. 
by influence from "Mohammaden laws, the doctrine of which many Chinese are bound by conversion (overgang) or by marriage with women ... completely exclude community property., 28

From the 1840s forward, Dutch and other European merchants petitioned the colonial government against the alleged Chinese abuse of the wife's separate estate in bankruptcy cases. While admitting that Arab and Chinese "intermediation (tusschenkomst) [was] a necessary evil (noodzakelijke kwaad) in the commerce between the European and the actual native (eigenlijke Inlander)," the state-owned Netherlands Trading Company informed the government that Chinese and Arab merchants "have ... struck such deep roots of bad faith (kwade trouw), that strong legal regulations to extirpate the evil are needed in order that commerce will not be allowed to languish." ${ }^{29}$ If Arabs and Chinese were the main "Foreign Oriental" traders in the colony, it was the Chinese who were singled out for regulation: "We are referring here mainly to the Chinese, whose institutions presuppose that their marriages are excluded from community property.... [It] was often the occasion, that when insolvencies were discovered, the suspected properties of the husband had been transferred to the wife, [so that] creditors could assert no rights on them on the grounds that her marriage was said to be contracted with the exclusion of community property.",30

In Dutch civil law, husband and wife had community property marriage by default, unless a prenuptial agreement had been contracted. While community marital property entitled divorcees and widows to a definite portion of the couple's estate, it also bound her to her husband's debt. ${ }^{31}$ The European merchants requested that Chinese "marriages [be] contracted (aantegaan) in such a way that the rights of the third party cannot be defrauded." More specifically, they wanted the same civil law rights and duties for the Chinese so that "every Chinese who intends to be married but be excluded from community property marriage, be obliged to consider the formalities that the law prescribes for Europeans, and that by default of those formalities, the property of the wife, in case of insolvency, will be considered to belong to the [marital] community." 32

\footnotetext{
28 "Aansprakelijkheid eener Chinesche vrouw voor de Schulden van Haren Echtgenoot, 23 May 1766" [Liability of a Chinese woman for the debts of her spouse], in J. A. Van der Chijs, ed., Nederlandsch-Indisch Plakaatboek 9 (Batavia: Landsdrukerij, 1891), 130-32.

${ }_{29}$ Netherlands Trading Company Factor to Wichers, 9 July 1847, in De Nationaal Archief, Archief Ministerie van Koloniën 1850-1900 (henceforth AMK), Inventaris nummer (Inv.) 2 Nov. 1902, 621; Mailrapport, 17 July 1857, no. 30.

${ }^{30}$ Ibid.

${ }^{31}$ See title 6, book 1 (Persons), Burgerlijk Wetboek voor Nederlandsch-Indië (Civil code for Netherlands-India); Art. 866, Wetboek van Koophandel voor Nederlandsch-Indië (Commercial code for Netherlands-India).

32 Netherlands Trading Company Factor to Wichers.
} 
Although, as we have seen, Chinese officers were conscious of the difference between Chinese and creole Chinese legal norms, they were only asked to represent the inheritance laws of the "Chinese kingdom." In reply, they stressed the patrilineal ideology of Chinese inheritance law: (1) "A Chinese girl who marries goes over to the lineage (geslacht) or the "Sin" of her husband, neither she nor her children share any further community with the lineage in which she was born (Civil Code, art. 844, 845, 846)"; (2) "The maternal line does not come into consideration. The paternal [side] inherits everything. By the absence of further relatives, the relatives of the mother are not considered, but the legacy falls to a public device for the conservation of the ashes (Soetung) (art. 848, 850, 851)"; and (3) "A real Chinese considers a woman only as a [means] necessary for the establishment of the male lineage. One does not recognize her rights, she always stands under guardianship, even as the widowed mother, [she is] under that of her oldest son. She also inherits nothing else, but that which is given to her out of benevolence (art. 852)."33

Combining European demands for civil law regulation with the inheritance law of China, the Governor-General adopted a marital property regime for the Chinese that twice disadvantaged Chinese women. Community property would continue to be excluded for the Chinese, but for precisely the opposite rationale from its eighteenth-century statutory predecessor. While the abovementioned 1766 statute had granted Chinese women separate estates for protection against their husbands' debts, "separate" now meant subsuming all property to be under their husbands' legal ownership unless otherwise proven. The Supreme Court judge Fokko Alting Mees warned that without civil law's protection of women's rights, the state should at least take into account that the local Chinese recognized, "It is possible [for the wife] to exercise all deeds of management and ownership without the permission and authorization of the husband." ${ }^{34}$ The 1855 Statutory Law (Staatsblad) no. 79 remained equivocal on this point. Article 2 of the statute stipulated that "profits accruing to the wife, in a standing marriage, from her own affairs or trade, cannot be otherwise proven than by proper written evidence."

The case of Lie Tjoenio's failure to retain what she claimed was her property against her husband's creditor (another Chinese subject) illustrates how the colonial courts put the new law into practice. On 22 October 1859, the Batavia Court of Justice impounded objects from the household of an indebted Chinese man. More than a week later, on 2 November, Lie Tjoenio, the debtor's wife, filed a lawsuit to prevent the public auction of what she claimed was her property. She pleaded that while her husband "lived together with her, he was neither the owner, nor the tenant of the house, wherein the detained properties

33 ibid.

34 F. Alting Mees aan Algemeene Secretarie (General Secretariat), 22 June 1852, in Nationaal Archief, AMK, Inv. 2 Nov. 1902, 621; Mailrapport, 17 July 1857, no. 30. 
were mentioned, [and] neither [was he] the owner nor the possessor (eigenaar ... bezitter) of those properties." 35 Lie made her claim based on her ownership or tenancy of the house. Following the older marital property regime for the Chinese, the Court of Justice was satisfied with this claim as long as she was willing to back it up with an oath made "in the customary way of her nation." She did and won her case. However, the Supreme Court, citing Article 2 in Staatsblad 1855 no. 79, annulled the decision of the Batavia Court of Justice.

Lie Tjoenio's plea became part of a recurring pattern over the next half-a-century, in which creole Chinese women staked their claims to impounded household properties based on their inherited ownership or tenancy of the matrimonial house. As I will explain below, colonial judges did not always apply the stringent burden of proof against these women, and in fact found a way to tacitly protect some women who did not have written proof of separate marital property. The passage of Staatsblad 1855 no. 79 incorporated the entire Chinese population in Java into the European court system for commercial disputes, but the question of separate or communal marital property could not be solved by legislation. Over the next forty years, Dutch judges would increasingly come to rely on Dutch Sinologists to determine the question of the Chinese woman's property rights.

\section{CONFUCIANIST ETHICS AS PATRILINEAL LAW}

Dutch attempts to codify a private legal status for the Chinese in Java since the 1860s did not come to fruition until $1917 .{ }^{36}$ In the meantime, Sinology-trained Dutchmen brought a new mode of Orientalist legal ethnographic reasoning to bear on Chinese law and the definition of Chinese women's property rights. This was part of a broader trans-colonial shift in the administration of personal law that saw native intermediaries replaced with colonial judges' more direct access to stabilized religious-legal texts. ${ }^{37}$ The discourse of comparative family law emerged at this time among colonial intellectuals and became a standard of a nation's evolutionary progress, in Henry Maine's terms, "from status to contract." 38 Where a nation's laws did not specify the relations of individuals within a family, these were to be deduced from the legal and religious traditions of that nation.

35 HRNI 19 (1862): 189-92.

36 For a thorough and technical reconstruction of Dutch legislative debates about inheritance law, see Tjiook-Liem, De Rechtspositie, 155-219.

37 In British India, colonial courts relied on Islamic and Hindu religious experts for adjudicating "personal law" disputes among Indian subjects until 1864, when judges turned to translated classical legal texts. Sharafi, Law and Identity in Colonial South Asia: Parsi Legal Culture, 1772-1947 (Cambridge: Cambridge University Press, 2014), 129-31.

38 For a critical history of the imperialistic ambitions of the comparative family law project, see Teemu Ruskola, Legal Orientalism: China, The United States, and Modern Law (Cambridge: Harvard University Press, 2013), 30-59. 
Mitra Sharafi argues, "The construction of Parsi law in British India differed sharply from the text-dependent process that forged Anglo-Hindu and Anglo-Islamic law." 39 Sharafi shows that the Parsi's in western India, through their relative wealth, precocious legal self-professionalization, and the absence of Zoroastrian religious texts, were able to lobby and win a separate personal law code based on patriarchal customary legal norms in 1865. In Dutch Java, the colonial state replaced legal advice from Chinese merchant officers with legal advice from "text-dependent" Sinology-trained Dutch officials. The conflation of Chinese law with Confucianist ethical teachings contrasts with the Dutch decision to adopt adat law for indigenous Javanese and other Indonesians. Whereas Islamic influences were deemed exogamous for native Indonesians, local creole practices were ignored in their ethnographic construction of Confucianist ethical law as an essentially foreign Chinese religious tradition.

Between 1854 and 1896, twenty-four government-selected young Dutchmen were trained in the written classical Chinese language, classical texts, and Southern Chinese spoken languages in Leiden University and in south China, before being deployed to cities with substantial Chinese populations in the Dutch East Indies as official "translators of the Chinese language" and "extraordinary members" of local probate courts. ${ }^{40}$ These Sinology-trained official translators and legal advisers brought a new ethnographic sensibility to bear on colonial legal questions about the Chinese woman's property rights. ${ }^{41}$ Although locally appointed Chinese officers were still consulted for Chinese legal norms, the Sinologists' ethnographic opinions would increasingly become the authoritative positions on questions of family law and Chinese women's property rights in particular.

Two Dutch civil law doctrines that protected women's rights were at stake in these family law debates among jurists and Sinologists. The Dutch inheritance law ensured equal rights to inherit between daughters and sons (legitieme portie) up to three-quarters of the estate. And as mentioned earlier, Dutch marital property was by default communal (gemeenschap van goederen), unless otherwise specified in pre- or postnuptial contracts. The husband and father was the legal head of the household for all contracts. "To give something in contracts," according to Dutch civil law, "is understood as the duty to deliver the thing, and to care for the preservation of the same, until the point of time

39 Sharafi, Law and Identity, 138.

40 Pieter N. Kuiper, "The Early Dutch Sinologists: A Study of Their Training in Holland and China, and Their Functions in the Netherlands Indies 1854-1900" (PhD thesis, Leiden University, 2015), 11-13.

41 The Dutch Sinologists brought their Chinese Mandarin tutors-imperial provincial examination graduates - to the Indies to serve as personal secretaries throughout their translation and advisory careers. See the biographies of the Sinologists in Kuiper, "Early Dutch Sinologists," 828-945. 
forth delivery, as a good housefather." ${ }^{, 2}$ It was not until 1934 that the married Dutch woman could contract without her husband's explicit authorization, and until 1956 that she had separate marital property by default. ${ }^{43}$ Used to their patriarchal powers, male jurists fresh from the metropole found it difficult to acknowledge the autonomy of property-holding creole Chinese women representing themselves in contracts and in law.

Take the case of Liem Gowienio and Liem Tjoenjo, who represented themselves in the Semarang Court of Justice in 1859. It became a matter of legal contention for both whether "married Chinese women could enter proceedings as plaintiffs without the authorization of the husband." Having to publicize the new patriarchal orthodoxy, the law journal noted, perhaps with the inevitable irony, "Thereupon (these two women) produced permissions from their spouses for the performance of the case." ${ }^{44}$ In more complex inheritance and debt-recovery disputes, colonial jurists would turn to the Sinology-trained translators for expert advice on Chinese legal norms.

Dutch Sinologists in Java constructed "Chinese law" by supplementing the Qing legal code concepts with orthodox Confucianist ritual treatises and ethnography in South China. ${ }^{45}$ Gustaaf Schlegel, the first Sinologist deployed in Batavia in 1862, laid the foundations for this approach. ${ }^{46}$ As he explained in an early writing about Chinese marriage law and customs in the local law journal, the Qing Code was a penal code, while "customary ceremonies ... are altogether civil." To understand Chinese legal norms for marriage and marital property then, it would be "necessary to render that part of the physical law code ... before going over to the description of the [marriage] ceremonies." ${ }^{27}$ While it was clear from the Qing legal code that marriage was an exchange between two families, Schlegel noted in his ethnographic description that the bride's "family prepares ... her bridal gift (bruidsschat), consisting of clothes, jewelry, tables and stools, furniture and such articles." ${ }^{48}$ This civil

${ }^{42}$ In de verbindtenissen om iets te geven is begrepen de verpligting om de zaak te leveren, en voor derzelver behoud, tot op het tijdstip der levering, als een goed husivader te zorgen (Art. 1235, Dutch Civil Code).

${ }^{43}$ Govaert C.J.J. van den bergh, "Gehuwde vrouwen en (on)vermogen" [Married women and (in)capacity], in Rikki Holtmaat, ed., Eeuwige Kwesties: Honderd Jaar Vrouwen en Recht in Nederland [Timeless questions: a hundred years of women and rights in the Netherlands] (Deventer: W.E. J. Tjeenk Willink, 1999), 12-23, esp. 19-20.

44 "Liem Gowienio en Liem Tjoenjo ca. Souw Toeansang en Tan Hoknio," HRNI 17 (1859): 84-89.

${ }^{45}$ See also Kuiper, "Early Dutch Sinologists," 538-47.

46 Two fuller treatises in the 1890s followed his approach: J. W. Young, Het Huwelijk en de Wetgeving Hierop in China [Marriage and legislation on the subject in China] (Batavia: Albrecht \& Rusche, 1894); and G. von Faber, Het Familie- en Erfrecht der Chineezen in Nederlandsch-Indië [The family and inheritance law of the Chinese in Netherlands India (Leiden: Eduard Ijdo, 1895).

47 Gustaaf Schlegel, "Wettelijke Bepalingen omtrent de Huwelijken in China en Beschrijving der Daartoe Gebruikelijke Plegtigheden," HRNI 20 (1862): 394-408, 394. Schlegel would later become the first professor of Sinology at Leiden University (1877-1902).

${ }^{48}$ Ibid., 405. 
practice did not constitute a right in Schlegel's interpretation. He noted on Chinese inheritance practices that "daughters received nothing. The testator can however give his unmarried daughters a small legacy as bridal gift." 49

Schlegel relied on a purist notion of Confucianist social logic when he testified in court on the question of Chinese women's property rights. "The (Chinese) woman is seen rather as an object (zaak) and a means for the reproduction of the male lineage, than an independent personality with her own destiny and rights." ${ }^{50}$ In his report, Schlegel cited neither the Qing code nor marriage ceremonies, but rather a popular Confucianist adage that prescribed women's lifelong subjection to the authority of fathers, husbands, and sons. To claim "that a Chinese woman can possess something, is, according to Chinese ethics, an absurdity.... A Chinese woman has nothing; her diamonds, clothes, in short, all that she brings with her to her marriage, by the fact of her marriage itself comes to the possession of her husband." ${ }^{51}$ Except for a brief interlude in the late $1870 \mathrm{~s}$, Schlegel's purist construction of Chinese law remained the orthodox ethnographic wisdom in this period of study.

In 1876, the new translator W. P. Groeneveldt testified that the father's bridal gift could be interpreted as the daughter's inheritance right. ${ }^{52}$ The male heir in China, he argued, had "the duty to provide maintenance and to give [their sister] a trousseau in proportion with her status and with the property he inherited." Groeneveldt admitted that this "right of the unmarried daughter to the inheritance of the father is not further regulated" by law. But, "If the brothers are found to be negligent, it is the duty of other family members to induce (anndringen) him, failing which the judge [in China] is empowered to see to it that ... he lives up to the duty." "The recognition of [this] slightest right already dispels" Schlegel's claim that "she exists as a thing (zaak).,"53

Groeneveldt's argument for greater legal recognition of Chinese women's property rights, especially in marital property law, was based on his observations of Chinese social life in Java. This was later on expressed in a memorandum criticizing a draft private law code (1872) for the Chinese in Java, which, as a result of Schlegel's Sino-centric ethnographic advice, would have denied women any rights to separate marital property. ${ }^{54}$ He pointed out that most

49 Schlegel, "Chineesch Regt: Iets over Chinesche Testamenten, Donatiën, en Erfopvolging," HRNI 20 (1862): 369-74, 372.

50 "Berigten van Deskundigen" in IWR no. 142, 1866, 43-44.

51 Ibid., no. 154, 1866, 3-4.

52 Groeneveldt was asked to review whether "according to inheritance laws valid in China, children inherited without distinction of sex from their father and if so by what proportions." W. P. Groeneveldt, Lie Hoet Seng, Lie A-Lim, "Rapport van Deskundigen" (24 Sept. 1877), in "The Pitnio ca. The Tianseng en The Wantjiang (Het Hoog GeregtsHof van Ned.-Indie, 2 May 1878)," HRNI 30 (1878): 384-94.

53 Ibid., 388-89.

54 Groeneveldt aan Minister van Kolonien, 6 Mar. 1877, in Nationaal Archief, AMK, Inv. 2 Oct. 1902, 3000; Mailrapport, 16 June 1877, no. 44. 
Chinese in Java started out as "small shopkeepers or craftsmen," who would not anyway have had the means to worry about marital property. But in cases where couples did accumulate some wealth over time, "it was certainly also for a good part to the credit of [the wife's] labor." It was only fair for Chinese women to enjoy the protection of community property marriage. Groeneveldt's championing of the Dutch doctrine of community marital property rights for Chinese women in Java would only be realized when the longdebated drafts of Dutch-Indies Chinese private law were finally enacted in 1919.

Groeneveldt's pragmatist voice was soon drowned out by the purists. In 1879, the Indies law journal published a realist-purist construction of Chinese law regarding women's status written by Surabaya translator, P. Meeter. For a people conditioned by Confucianist precepts as a state religion and unfamiliar with the rule of law, Meeter thought colonial law had to go out of its way to enforce patriarchal norms like the Confucianist state in China. Comparing contemporary China with Abrahamic Israel, where polygamy and daughter-trading were permitted, Meeter contended that the "theory of the Chinese Government [was] undoubtedly patriarchal." ${ }^{, 55}$ Chinese patriarchal power was prescribed by the classical text "Li Ki" (Book of Rites), which for him served as the "political ethics of Confucius" and the "basis for the state religion" (staatsgodsdienst). Wherever the Qing Code remained silent on women's status, or "when the advice of the legal experts conflicted," it became "necessary to go to the source and consult the Book of Rites." 56

A rights-based conception of colonial law such as Groeneveldt's would only open legal institutions to abuse by the Chinese. Meeter's realist standpoint stemmed from his observation that the Chinese often contrived to circumvent probate and bankruptcy proceedings. For instance, he claimed it was common for dying husbands to transfer property to their wives in order to prevent probate administration of their estates for minor heirs. A more serious abuse involved the transfer of property to the wife's name before the merchant's fraudulent declaration of insolvency. In Meeter's conception, the colonial state ought to hold the Chinese father accountable by recognizing his absolute powers over his family. This realist-purist position on Chinese law would gain the upper hand in the colonial courts moving into the $1880 \mathrm{~s}$ and 1890s. ${ }^{57}$

${ }_{55}^{55}$ Meeter, "De Regtstoestand," 345-73.

${ }^{56}$ Ibid., 349.

${ }^{57}$ A father's testament to appoint his sole surviving widow (a secondary wife) as guardian for their two younger sons at the expense of his eldest son (by a deceased primary wife) was successfully challenged by the latter. The courts cited Meeter's report, and ordered instead an equal division of the estate between the surviving widow and all three sons. Oeij Kim Nio ca. Tan Liong Sam (Hoog Geregtshof van Nederlandsch-Indie, 5 Feb. 1880), HRNI 34 (1880): 131-38. 
The Sinology-trained Dutchmen brought a more text-dependent construction of Chinese law to Java. In the process of debating how Chinese law ought to be applied to disputes involving creole Chinese women in Java, the Qing legal code, Confucian treatises, and observations about social life in China and Java were brought into the legal ethnographic debates. Groeneveldt might have disputed Schlegel's and Meeter's more purist constructions of patriarchal Chinese law, but over the long run, a Confucian ethicist conception of Chinese family law became entrenched in the Dutch colonial law. The upsurge of fraudulent contracts made in the name of women during the economic crisis of the 1880 s made the adoption of a full-fledged patriarchal Chinese law more urgent.

\section{AFFINAL OBLIGATIONS, DOCTRINAL CONTRACTS}

During the boom and bust decade of the 1880s, the Dutch colonial state once again faced demands from Dutch merchants to pass tougher laws against fraudulent Chinese insolvencies. ${ }^{58}$ It was in this context that many creole Chinese women had to go to court to defend their separate estates against confiscation by the state for their husbands' creditors. By far the most bitterly contested case by a creole Chinese woman in this period, however, was fought to defend not so much herself against a third-party debt but the validity of a mortgage contract in law, which was conceived as an affinal moral obligation in creole Chinese kinship terms. The feud between colonial probate authorities and this complex of affinally connected interests exposed inherent contradictions in Dutch judges' doctrinal beliefs in the Chinese woman's freedom to contract, and the probate authorities' conviction that affinal connections were not Chinese.

To begin with, Dutch judges hearing Chinese women's appeals were not always bound by the Sinologists' patriarchal construction of Chinese law. During the credit crisis of the later 1880s, judges created new precedents to protect married Chinese women's separate property, where the combined effects of the 1855 Statute no. 79 and the purist construction of Chinese law would have subjected their goods to their husbands' debts. Dutch judges did not demand notarial proof of the women's claim of their separate ownership of jewelry and household objects as required by the 1855 statute. Tjan Pan Nio of Surabaya was a "public merchantwoman" (openbare koopvrouw), who cited the presence of her father's ancestral tablet as proof of her tenancy of the house. ${ }^{59}$ Tan Hong Nio of Pasuruan had proof of her ownership of their marital residence in the form of her mother's testament. Despite still

\footnotetext{
58 John Furnivall, Netherlands India: A Study of Plural Economy (Cambridge: Cambridge University Press, 1944), 196-97, 207; Claver, Dutch Commerce, 76-120.

59 "Tjan Pan Nio ca. Lim Tjoe Nio en Tjiok Oen Tjia” (Hoog-Gerechtshof van NederlandschIndie, 7 Apr. 1887), HRNI 48 (1887): 387-94.
} 
sharing the same residence, she claimed estrangement from her husband, and separation of their retailing (toko) and cooking arrangements. ${ }^{60}$ In both cases, the Supreme Court made new precedents to protect their property claims against their husbands' creditors.

What remained contested among the colonial authorities was the question of the Chinese women's freedom to contract, and how their names were often used fraudulently in contracts signed by her husband and/or brother. The longrunning case of Ong Kwie Nio's feud with the Batavia probate court that lasted throughout the 1880s and ended in the Supreme Court exposed the inherent contradictions between Dutch Sinology's patrilineal theories, Dutch judges' doctrinal belief in Chinese women's freedom to contract, and the bilateral structure of kinship that conceived of moral obligations in affinal in addition to patrilineal ways.

Ong Kwie Nio's f290,000 mortgage loan to her brother was most likely such a fictitious loan made by her husband, Kapitan Oeij, to secure the bilateral family's Tangerang lands against the accumulating debts of the brother(-in-law), Ong Boen Seng. We know this from the case the probate court constructed against Kwie Nio after it took over the account books of Boen Seng's estate in 1881. Boen Seng had already mortgaged five-sixths (f515,000) the total value of his lands when he "borrowed" the sum from his sister. Shortly thereafter, he stood as a guarantor for Thung Siong Kie, Chinese lieutenant of Buitenzorg, for two consignments of goods (probably opium) worth f112,648 from the Batavia-based Scottish firm Maclaine Watson en Co. While Thung did partially default, he was able to settle his debt with Boen Seng. Had Thung defaulted on the entire sum, Boen Seng, liable for his debt, would have gone bankrupt, in which case the fictitious mortgage would give his sister about a one-half share claim to his total debt (estate). This would have hurt the other real creditors. In the event, the mortgage contract lay dormant.

Initial exchanges between the head of the bilateral Ong-Oeij family and the probate authorities revealed the conflict between affinal and patrilineal conceptions of guardianship by "Chinese" law. Differences arose out of Ong Boen Seng's sudden intestate death in 1881. To condense a complex story, Boen Seng's brother-in-law, Kapitan Oeij, who had leased and lived on Boen Seng's lands (and hence was uxorilocal kin), risen to be Chinese Kapitan of the locality, served as his general agent for twenty years, and managed his funeral, was initially prepared to forgive the 1879 sister-brother loan if the probate authorities would let him be the guardian of Boen Seng's children and the estate. But the probate authorities turned down his offer. ${ }^{61}$

\footnotetext{
60 "Tan Hong Nio ca. Het Vendukantoor te Pasoeroean en Tjoe Tan Ngo," HRNI 52 (1889): 385-92.

61 ANRI: Arsip Wees- en Boedelkamer 1819-1937, file 1746, Ong Boen Seng: “Oeij Tjiang Piauw to Collegie van Boedelmeesteren, February 28, 1881; August 20, 1881."
} 
Kapitan Oeij's reply indicated how the elite creole Chinese were conscious of Dutch legal strictures but were convinced that moral obligations should supersede the law. In a Dutch language letter probably drafted by his lawyer, Kapitan Oeij protested against being "reproached [by the probate court] for intervening in Ong Boen Seng's estate, to which [he was told] he did not have the least right." Feeling "very sore" (zeer gevoelig) by the reproach, Oeij declared that "while he might not have the legal rights,... he felt obliged (verpligt) and well-grounded [in his claims] from a moral viewpoint (zedelijke oogpunt)" to claim guardianship. ${ }^{62}$ Adjudicated by a Dutch judge in the native Landraad, and advised in Chinese "religious concepts" by "experts" including Groeneveldt, the probate court was ordered to stand in as guardian for the two sons of Boen Seng. ${ }^{63}$

If law had deprived them of their affinal guardianship obligation, Kapitan Oeij and his wife were determined to recover it by other means. To win back guardianship and control of Boen Seng's estate from the probate guardianship, the by-then widowed Ong Kwie Nio first arranged a cross-cousin marriage between her daughter and Boen Seng's elder son, Ong Pit Tiang. ${ }^{64}$ Marriage conferred automatic adulthood and the legal right to withdraw one's inherited portion from probate guardianship. ${ }^{65}$ The matriarch was clearly the master manipulator, for within six months of the marriage, Ong Pit Tiang had sold his lands to his paternal aunt, who was now also his mother-in-law. ${ }^{66}$ Through another son-in-law, Kapitan Lim Tjong Hien, Ong Kwie Nio appealed for Ong Pit Tiang to become the legal guardian of his younger brother Ong Hok Tiang's estate. This was turned down on account of Pit Tiang's lack of experience. ${ }^{67}$ Unable to retrieve Hok Tiang's land, the matriarch pressed on with recalling the dormant loan from 1878 .

62 “Oeij Tjiang Piauw to Collegie v. Boedelmeesteren, August 20, 1881,” ANRI: Arsip Wees- en Boedelkamer 1819-1937, file 1746, ONG BOEN SENG.

63 The estate had been awarded to Boen Seng's two sons born by two secondary wives. There was no indication that the three wives of Boen Seng were going to contest the estate among themselves. The probate court most likely instigated Boen Seng's primary wife to claim the estate for her two daughters to the exclusion of his sons by two secondary wives, in accordance with Dutch policy to apply Dutch inheritance law in intestacy cases. In the trial, Kapitan Oeij testified in favor of both of Boen Seng's sons. See ANRI, Arsip WBK, no. 1746, Ong Boen Seng, and "Lim Kwie Nio etc. ca. Ong Doortje Nio, College van Boedelmeesteren” (Landraad Batavia, 17 Oct. and 19 Dec. 1881), HRNI 40 (1883): 229-41.

${ }^{64}$ The probate court was first informed by a son-in-law of Ong Kwie Nio; see "Kapitan Liem Tjiong Hien to College van Boedelmeesteren in Batavia, August 7, 1883," ANRI: Arsip WBK, 1746, Ong Boen Seng.

${ }^{65}$ Meeter saw how "the management of their legacies by the probate courts ... [was] a thorn in the eye," and how marriages were arranged for "barely adult" children, so that they might immediately assume legal adulthood and prevent probate intervention. See "De Regtstoestand," 369.

66 "Lie Pektat's note to College van Boedelmeesteren, May 22, 1884," ANRI: Arsip WBK, 7262, Ong Boen Seng.

67 "Note on Kapitan Lim Tjong Hien's letter to College van Boedelmeesteren, August 7, 1883," ANRI: Arsip WBK, 1746, Ong Boen Seng. 
In retaliation, the probate court sued Ong Kwie Nio for colluding with his brother to make up the fraudulent loan. The plausible motive for fraud I recounted above was reconstructed by the probate authorities in the present case. Furthermore, the probate court's lawyer, citing Schlegel's and Meeter's Confucianist dictum about women's incapacity to own property, challenged her to prove that "she had withdrawn her own money out of her purse" for the loan. ${ }^{68}$ Knowing that it was her husband who managed their bilaterally amalgamated estate, the lawyer demanded proof of her personal conscious authorization of the mortgage loan of 1879. Cross-examined with an oath administered in the main Chinese temple in Batavia, she made the following statement: "I remember my husband ... informing me in 1878 that he had loaned a sum of f290,000 of my money, which was under his care, to my brother, and that later on he let me know that Ong Boen Seng had bound his immovable property as security to the repayment of that sum."69 This amounted to a confession that she did not sign the mortgage contract herself back in 1878. But the judges at both the Raad van Justitie and the Supreme Court still decided in her favor. The Supreme Court ordered the probate court to pay Kwie Nio f145,000 (half the loan) out of Boen Seng's estate on behalf of his second son.

Dutch judges maintained their prevailing doctrinal stance that married Chinese women were free to contract in their own names. The Supreme Court judge in this case, Sibenius Trip, had been a proponent not only of married Chinese women's freedom to contract, but also of their right to separate matrimonial property. ${ }^{70}$ The evidence that the probate court had assembled to argue for fraudulent intent was rejected as circumstantial to the fact of the legally written contract between Kwie Nio and her brother. ${ }^{71}$ Juxtaposed against Ong Kwie Nio's confession, this amounted to an admission by the judges that the woman's retrospective oral approval of contracts signed by her husband in her name was legal.

While the probate court was correct about the fictitious nature of the loan between the siblings, the Dutch Sinologists' theory of Chinese patrilineal law set it up to collide with the bilateral interests of creole Chinese families. The matriarch Ong Kwie Nio's bilateral division of her estate when she died three years later was further proof of the probate officials' misreading of

\footnotetext{
68 "Ong Kwi Nio ca. De Weeskamer," 42.

69 "Weeskamer te Batavia ca. Ong Kwee Nio" (Supreme Court, 10 Oct. 1889), Indische Tijdschrift van het Recht 53 (1889): 403-21, quote 420.

${ }^{70}$ In 1876 , he researched the legislative history of the 1855 Staatsblad no. 79 to show that the legislators had proposed to include an extra clause to guarantee the married woman's freedom to contract, although this was not included in the law's final version. Sibenius Trip, "Vraagpunten, mededeelingen en bermerkingen van verschillenden aard, betreffende Nederlandsch-Indisch regt," HRNI 27 (1876): 65-96, esp. 88-89.

71 "Weeskamer te Batavia," 419.
} 
creole Chinese kinship practices. That she forgave her nephew the f145,000 debt awarded by Dutch law suggests that the sister-brother loan of 1878 was most likely fictitious. ${ }^{72}$ The bulk of her estate consisted of jewelry and a few houses that could not have amounted to f290,000. She did, however, hold her own property separate from her husband's. Her division of her property shows how she identified more with both sides rather than just one of the bilaterally connected families. Remarkably, her own children, presumably already the heirs of Kapitan Oeij, were bypassed for inheritance in favor of Oeij's and Ong's nieces and nephews

The increased frequency of Chinese insolvency during the economic crisis of the 1880s brought to head ideological differences among the Dutch colonial authorities and between the creole Chinese and the Dutch over the question of Chinese women's property rights in the colony. If it was easier for the judges to protect Chinese women's matrimonial property when only husbands and wives were involved, the kinship logic behind the complex credit arrangements and familial politics among bilaterally connected creole Chinese kin remained opaque to the colonial authorities. Immediately after Kwie Nio won her trial, another allegedly fraudulent mortgage in central Java between a sister, a brother, and the sister's husband would plunge colonial jurists into a legal debate that ended the Chinese woman's freedom to contract in favor of patriarchal "Chinese law."

\section{CONTRACTUAL FREEDOM AS CIVILIZING STANDARD}

While Ong Kwie Nio defended her intra-familial mortgage contract against allegations of fraud, another Chinese widow in central Java tried to annul her mortgage by alleging an intra-familial fraud committed against her. If Kwie Nio's case had been framed around contract law, this latter case would quickly descend into an ideological contestation over Chinese women's legal status and their property rights. While Dutch jurists had refrained from taking an unequivocal stance against Chinese women's de facto contractual autonomy in Java, a turning point was reached with the trial over the fraudulent mortgage tied to Tan Paginio's house. By framing the question of women's freedom to contract as a question of national civilizational status, Paginio's lawyer managed to persuade the Supreme Court that creole Chinese women had to be assigned their national legal status of unfreedom within a broader global racial hierarchy of nations.

In 1879, Tan Paginio took out, at least on paper, a f10,000 mortgage on her house in the Chinese quarter of Tegal in a contract signed in the local resident's office. She would later claim that she only found out about this mortgage after her husband died (in 1883), and the local bailiff impounded her house for

72 ANRI: Wees- en Boedelkamer, Boedelpapieren 4240, Ong Kwie Nio en Oeij Gen Nio, 1899. 
public auction (1885). She "suspected" that it was "a fraud committed by her spouse in consultation with her brother" for debts they had jointly incurred in their operation of the opium revenue farm in Cheribon that year. ${ }^{73}$ The landmark trial pitted Indies-Chinese law against patriarchal Chinese legal notions of women's rights.

Both Tan Paginio and her creditor would frame their dispute not so much over the events surrounding the contract but the question of which law (Dutch civil, Indies-Chinese adat, or Chinese national law) should apply, and to what effect. Tan Paginio's bid to annul the mortgage and her unconsciously inherited debt had been twice accepted by the Semarang Raad van Justitie, only to be rejected both times by the same judge, Sibenius Trip, in the Supreme Court. While Tan Paginio denied knowledge of the mortgage, the creditor claimed that she herself had appeared to make interest payments in 1879. Trip disagreed with the Raad van Justitie that this was a question of the married woman's subjection to her husband's authority under civil law. ${ }^{74}$ Recall that in Ong Kwie Nio's case, Trip dismissed her husband's and her brother's plausible collusion as secondary to the sanctity of the contract written in her name. Here, Trip asserted that Paginio had framed her case wrongly by European civil law. As a marital property law question, it had to be judged according to the Chinese subject's family law in the native Landraad.

Paginio's third and final attempt to invalidate the mortgage thus focused lawyers and judges on the question of women's marital property in "Chinese law." But whose Chinese law, and what effect should it have on the Chinese woman in the Dutch East Indies? By the 1890s, Dutch jurists and Sinologists had developed two opposing ways of understanding Chinese family law in the Indies: terms like "pure Chinese law" (since 1865) or "law as it is applied in China" (since 1867), were set in opposition to "Indies-Chinese law" (since 1875) or "Chinese law that is valid in the Netherlands Indies" (since 1867) ${ }^{75}$ Although lawyers and judges were reliant on the Sinologists to interpret Chinese law, they were, like the Sinologists, divided between China-oriented purists and the Indies-focused pragmatists. The trial became an ideological contest between the two views. C. W. van Heekeren-a lawyer who would remain a life-long advocate of an Indies-centered approach to Chinese legal norms in the Indies - found his way to the cause of the creditor

\footnotetext{
73 “Tan Paginio ca. Lim Eng Tjae, Raad van Justitie te Samarang (13 Jan. 1886)," in IWR, no. $1222,1886,190-92$.

${ }^{74}$ This was the second round. See "Liem Tiang Keng ca. Tan Paginio," HRNI 54 (1890): 178-90. In the first round (1886), he had disagreed with the Raad on the legal technicality that required valid contracts to include at least the local assistant resident's signature. "Tan ca. Lim (13 Jan. 1886)," in IWR, no. 1222, 1886, 190-92; “Tan Paginio ca. Lim Eng Tjae, Hoog Gerechtshof van Ned.-Indie (22 Nov. 1886)," in IWR, no. 1225, 1886, 201-4.

75 Von Faber, Familie- en erfrecht, 36-37.
} 
Liem Eng Tjae. ${ }^{76} \mathrm{C}$. Th. van Deventer, who would later be a leading champion of the Dutch civilizing mission, the "Ethical Policy," represented the purist argument for Tan Paginio's quest to annul the mortgage.

Van Heekeren's Indies-Chinese legal developmentalist theory won the first round in the Landraad for the creditor, upholding Paginio's contracted debt. ${ }^{77}$ Van Heekeren added legal historical depth to Groeneveldt's observations of Chinese social life in the Indies. Settlement, intermarriage, and living under Dutch Company laws for the Chinese, he maintained, created a set of unique "Javanese-Chinese laws." This history of legal development included Company-era statutes that granted the Chinese their own probate officials (1642), unmarried Chinese women in Java autonomy at the age of twentyfive (1693), and separate marital property for women (1766). Van Heekeren also cited a survey of the archives (protocollen) of four local Batavia public notaries, where he found "deeds wherein married Chinese women, without the endorsement of their spouses, appear [before the law] and buy and sell in autonomy; issue powers of attorney, seal contracts of loans, etc." Like in Justinian's Roman digests, he argued that four hundred years of statutory and the customary legal norms had formed a body of law for the Chinese in the Indies that supported the Indies-Chinese woman's right to separate estate and contractual freedom.

At the Raad van Justitie, van Deventer dismissed van Heekeren's "Javanese-Chinese law" as a lawyer's fiction. ${ }^{78} \mathrm{He}$ cited P. Meeter to characterize the concept of an Indies-Chinese customary law as "a fiction, thought out by the clever Chinese chiefs or their handy lawyers." Moreover, his own survey of public notaries "in Tegal, Pekalongan and Semarang [showed that] all notarial deeds, to which married Chinese women bound themselves, were invariably endorsed by their spouses." For van Deventer, the 1855 statute gave Chinese women the right to own their separate property but the right of management and disposal remained in the hands of the husband. Tan Paginio might have owned her house, but the disposal of it was not in her authority as a married woman. It could "simply be sought ... in the legal status of the married Chinese woman according to religious laws, folk institutions and usages valid in China." In short, citing Meeter again, Chinese "legal conceptions" can be found in the "pronouncement[s] of Confucius." Siding with van Deventer, the judge added a racial-civilizational twist: "In the year of 1891, most European legislatures had still not accorded European married

\footnotetext{
${ }^{76}$ See his Beschouwingen over het voor Chineezen op Java Geldende Recht [Some thoughts on the official law for the Chinese in Java] (Semarang: G.C.T. van Dorp, 1901).

77 “Tan Pa Ginio ca. Liem Tiang Keng (4 October 1890, Landraad te Tegal)," in IWR, no. 1464, 1891, 113-16.

78 "Tan Pa Ginio ca. Liem Tiang Keng (22 April 1891, Raad van Justitie te Samarang)," in IWR no. 1464, 1891, 113-16; "Tan Pa Ginio ca. Liem Tiang Keng (11 January 1892, Hoog-Gerechtshof van Ned-Indie)," HRNI 58 (1892), 215-54.
} 
woman the authority," so that subjects in the colony must be "unfit" for such rights.

Judge Trip affirmed the Raad van Justitie's ruling that the Chinese woman in the Dutch Indies was not authorized to sign contracts without the assistance of her husband. Tan Paginio, like Ong Kwie Nio, most probably knew of and acquiesced in the lending of her house as credit to the operations of her husband's and brother's enterprise. For Trip, who had been supporting Chinese women's contractual freedom in the Supreme Court for almost twenty years, encountering this particular mode of bilateral Chinese credit networking probably changed his mind about Chinese women's contractual freedom in the colony. By affirming Paginio's claim that her husband and brother had defrauded her house against her knowledge, the judicial decision saved Tan Paginio's house from confiscation, but it also ended married Chinese women's right to separate estates and contractual autonomy.

\section{CONCLUSION}

The legal domestication of the creole Chinese woman in Java proceeded in hesitant steps in the second half of the nineteenth century. While colonial legislators were at first primarily concerned with deterring Chinese male merchants from manipulating their wives' names and assets to defraud their creditors, what the colonial jurists encountered were strategies to extend credit across bilaterally connected creole Chinese families through affinal and matrilateral ties. Women were at the center of these alliances not so much as traders themselves but, as Ong Kwie Nio's case indicates, manipulators of marriages and assets within the bilateral families. Sinology-trained Dutchmen began to represent Chinese family or civil law for the Dutch colonial courts from abstract ideals of Confucianist social ethics from the 1860s. Although local born Chinese officers in Java were well aware of two different sets of norms for the Chinese in Java and in the Chinese homeland, their views were gradually sidelined as text-dependent and China-oriented Sinology gained the upper hand in legal circles. Dutch or Eurasian lawyers, notaries, and judges in the colony were aware of the fact of creole Chinese women's inheritance rights and their dominance in household-economic matters, and they must have been complicit in acquiescing in their husbands' use of their assets, with or without their knowledge. The economic crisis of the later $1880 \mathrm{~s}$, however, became a turning point for colonial jurists. While judges protected some women's personal wealth from their husbands' debts, the confusion over women's role in contracts made among family members, with or without their knowledge, was exposed in prolonged disputes over mortgages made out in Ong Kwie Nio's and Tan Paginio's names. By the 1890s, lawyers like C. Th. van Deventer, who bore a civilizing mission, insisted that only civilized subjects were entitled to civil law rights. To avoid legal confusion, creole 
women had to be subject to the authority of the Confucianist head of the household.

By highlighting the gender politics of Dutch Confucianist family lawmaking, I have argued that the history of colonial law-making did not just add or subtract rights, but also reshaped the social structure of the creole Chinese community in Java. The gendered nature of Dutch ethical Confucianist rule of family law displaced an earlier creole social configuration that tolerated, if it did not acquiesce, in the creole Chinese woman's manipulation of her wealth and marriages in familial alliance strategies. Dutch colonial law's role in the Sinicization of Chinese law in Java raises at least two questions about our current understanding of the history of gender and race relations in Indonesia that deserve further attention. Historians of gender in Java/Indonesia have started to question the longstanding claim, since the $1950 \mathrm{~s}$, that women's autonomy in the domestic sphere was part of the defining cultural identity of Indonesia and the region. ${ }^{79}$ Reframed in gender terms, women remained subordinate to men, especially, as Barbara Andaya explains, after the introduction and growth of world religions in the region in the early modern period (1400-1800). ${ }^{80}$ Even women's prominence in the market can be read as a form of ritual subordination, given the traditional Javanese view of the market as a ritually contaminating space. ${ }^{81}$ But colonial law, especially adat law, remains curiously absent in this new gender theory-informed scholarship. The case of the legal domestication of creole Chinese women in the nineteenth century raises comparative questions about the social structuring role of colonial adat law and the lives of native woman in the nineteenth and early twentieth centuries. Were there ongoing fragmenting forces that were halted by the imposition of adat law, and did women's prominent role in the market and the household remain static in the nineteenth and early twentieth centuries?

The Confucianization of creole Chinese legal status since the 1860s also raises questions about the history of legal-race-formation in Indonesia's plural society. The origins of a more assertive, modern Confucian revivalist identity among the creole Chinese in Java is usually traced to the exile of late Qing China's political reformers in Southeast Asia in $1897-1898 .^{82}$ Historians have looked to the non-territorial dispersal of Chinese subjects across the East Indies, and their universal involvement in trade rather than agriculture,

79 Diane Wolf, "Beyond Women and the Household in Java: Re-Examining the Boundaries," in Juliette Konig et al., eds., Women and Households in Indonesia: Cultural Notions and Social Practices (Richmond, Surrey: Curzon, 2000), 85-100.

80 Andaya, The Flaming Womb: Repositioning Women in Early Modern Southeast Asia (Honolulu: University of Hawai i Press, 2006).

81 Suzanne Brenner, The Domestication of Desire: Women, Wealth, and Modernity in Java (Princeton: Princeton University Press, 1998).

${ }^{82}$ Lea E. Williams, Overseas Chinese Nationalism: The Genesis of the Pan-Chinese Movement in Indonesia, 1900-1916 (Glencoe: Free Press, 1960). 
to explain their incorporation into Dutch civil law jurisdiction, in contrast to the preservation of adat law for native Indonesians. ${ }^{83}$ The history of family lawmaking in Dutch Java suggests that a Confucian-ethical critique of creole cultural traits preceded the Confucian revivalist movement by close to four decades. Besides the territorial-economic logic, legal-ethnic lawmaking had embedded a proto-civilizing logic in their legal discourse that prepared the creole Chinese for their more decisive turn towards Chinese culturalist nationalism in the twentieth century.

\begin{abstract}
How did colonial family law reshape the ethnic and gender norms of a creolized entrepreneurial minority? While the literature on colonial Indonesia has tended to view the Dutch colonial preservation of adat (customary) law as helping to preserve Indonesian women's autonomy and property rights, this essay shows how, in the case of the Indonesian-Chinese entrepreneurial minority, the colonial government's institutionalization of Confucian "Chinese" family law gradually introduced more patriarchal norms for creole Chinese families. The Dutch colonial state's legal regulation of credit and commerce in Java took a moralistic turn in the mid-nineteenth century, giving shape to a more patriarchal and "Chinese" form of the family in Java by the century's end. This legal-moralistic turn took the form of a critique of creole Chinese women on one hand, and the Sinological construction of a body of Confucian "Chinese" private law on the other. For almost half a century, this encroaching colonial ethno-moral critique of creole Chinese credit manipulations and marriage arrangements came up against resistance from Peranakan Chinese matriarchs and patriarchs. In this article, I show how colonial Confucian family law eventually ended creole Chinese women's contract-making and credit-manipulating autonomies by subjecting the "Chinese" household to the civil law authority of the "housefather."
\end{abstract}

Key words: kinship, colonial law, family, gender, contracts, credit, Indonesia, overseas Chinese

${ }^{83}$ Fasseur, "Cornerstone and Stumbling Block." 